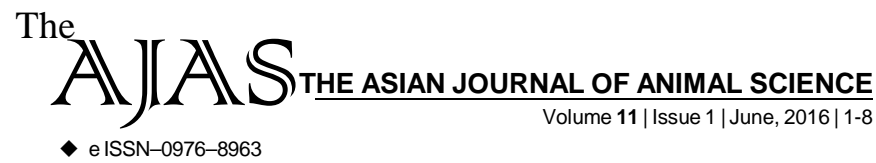

DOI : 10.15740/HAS/TAJAS/11.1/1-8 Visit us | www.researchjournal.co.in

RESEARCH ARTICLE.

\title{
Influence of chemical preservatives on the quality and shelf-life of dried Bombay duck (Harpodon nehereus)
}

\author{
TIRTHA BHATTACHARYA, TANUSHRI GHORAI, K.C. DORA, SREEKANTA SARKAR AND S. \\ CHOWDHURY
}

Author for Corresponding -

TANUSHRI GHORAI

Department of Fish Processing

Technology, Faculty of Fishery

Sciences, West Bengal University of Animal and Fishery Sciences, KOLKATA (W.B.) INDIA

Email: tanushrighorai@gmail.com

See end of the article for

Coopted authors'
ABSTRACT...... Dry fish is the low cost dietary protein source in India. Sometimes dry fishes are kept for a longer period that is the key factor of the deterioration of nutritional value of dry fishes, as they absorb moisture from the surrounding air. In the present study Bombay duck (Harpodon nehereus) were treated separately with saturated brine (Control, C), dry salt with 0.25 per cent potassium sorbate $\left(T_{1}\right)$ and saturated brine with 0.3 per cent sodium benzoate $\left(\mathrm{T}_{2}\right)$ and kept at ambient temperature for storage study after drying in open sun. The general purpose of this study is to determine the proximate composition of dry fishes treated with chemical preservatives and to investigate the quality changes of dried fishes with the increasing of storing period. The values for protein, fat, ash and moisture of dry fish for three different treatments were found in a range of 53.91 to 56.33 per cent, 5.94 to 11.77 per cent, 14.78 to 21.96 per cent and 6.9 to 7.42 per cent, respectively. The results of biochemical parameters revealed that during storage period, TVBN, TMA and PV content of $\mathrm{T}_{2}$ was better than $\mathrm{C}$ and $\mathrm{T}_{1}$ whereas TBA of $C$ was better than $T_{1}$ and $T_{2}$. The microbial parameters revealed that the quality of the dry fishes of both the samples $\left(\mathrm{T}_{1}\right.$ and $\left.\mathrm{T}_{2}\right)$, treated with preservatives, were of good quality and remain acceptable for longer duration than the control (C). Depending upon the sensory evaluation the overall acceptability of the dried fishes $\left(T_{1}, T_{2}\right.$ and $\left.C\right)$ was significantly declined during storage. The findings of this study showed that nutritional value of dry fishes treated with chemical preservatives give a better storage life than control.

KEY WORDS...... Drying, Bombay duck, Proximate composition, Biochemical parameter, Sensory evaluation

HOW TO CITE THIS ARTICLE - Bhattacharya, Tirtha, Ghorai, Tanushri, Dora, K.C., Sarkar, Sreekanta, and Chowdhury, S. (2016). Influence of chemical preservatives on the quality and shelf-life of dried Bombay duck (Harpodon nehereus). Asian J. Animal Sci., 11(1): 1-8 (DOI : 10.15740/HAS/TAJAS/ 11.1/1-8).

ARTICLE CHRONICLE - Received : 18.3.2016; Revised : 15.04.2016; Accepted : 08.05.2016 